ORIGINAL ARTICLE

\title{
Mobility and survival of Salmonella Typhimurium and human adenovirus from spiked sewage sludge applied to soil columns
}

\author{
J. Horswell ${ }^{1}$, J. Hewitt ${ }^{1}$, J. Prosser ${ }^{1}$, A. Van Schaik ${ }^{1}$, D. Croucher ${ }^{1}$, C. Macdonald ${ }^{2}$, P. Burford ${ }^{3}$, \\ P. Susarla ${ }^{4}$, P. Bickers ${ }^{5}$ and T. Speir ${ }^{1}$ \\ 1 Institute of Environmental Science and Research Ltd, Porirua, New Zealand \\ 2 Rothamsted Research, Rothamsted, Harpenden, Hertfordshire, UK \\ 3 URS Corporation, URS Centre, 13-15 College Hill, Auckland, New Zealand \\ 4 Moreton Bay Water, Moreton Bay Regional Council, Caboolture, Queensland, Australia \\ 5 North Shore City Council, Private Bag 93500, Takapuna, North Shore City, New Zealand
}

\section{Keywords}

human adenovirus, mobility, pathogens,

Salmonella Typhimurium, sewage sludge.

\section{Correspondence \\ Jacqui Horswell, Institute of Environmental Science and Research Ltd, PO Box 50-348, Porirua, New Zealand. \\ E-mail: jacqui.horswell@esr.cri.nz}

2008/2098: received 8 December 2008, revised 15 April 2009 and accepted 11 May 2009

doi:10.1111/j.1365-2672.2009.04416.x

\begin{abstract}
Aims: This study investigated the survival and transport of sewage sludge-borne pathogenic organisms in soils.

Methods and Results: Undisturbed soil cores were treated with Salmonella enterica ssp. enterica serovar Typhimurium-lux (STM-lux) and human adenovirus (HAdV)-spiked sewage sludge. Following an artificial rainfall event, these pathogens were analysed in the leachate and soil sampled from different depths $(0-5 \mathrm{~cm}, 5-10 \mathrm{~cm}$ and $10-20 \mathrm{~cm})$ after $24 \mathrm{~h}, 1$ and 2 months. Significantly more STM-lux and HAdV leached through the soil cores when sewage sludge was present. Significantly more STM-lux were found at all soil depths, at all time periods in the sewage sludge treatments, compared to the controls. The rate of decline of STM-lux in the controls was more rapid than in the sewage sludge treatments. Survival and transport of HAdV were minimal.

Conclusions: The presence of sewage sludge can significantly influence the transport and survival of bacterial pathogens in soils, probably because of the presence of organic matter. Environmental contamination by virus is unlikely because of strong soil adsorption.

Significance and Impact of the Study: This study suggests that groundwater contamination from vertical movement of pathogens is a potential risk and that it highlights the importance of the treatment requirements for biosolids prior to their application to land.
\end{abstract}

\section{Introduction}

Sewage treatment and disposal serve to isolate sewage from the community, thereby affording protection from pathogens capable of causing infectious diseases. However, sewage sludge is a valuable resource, containing high concentrations of plant nutrients that can be directly utilized by land application. Although it is accepted that pathogen numbers are reduced during sludge processing (e.g. anaerobic digestion), it is unlikely that they can be completely eliminated and this may be of potential signi- ficance for transmission of diseases in humans. One of the primary concerns with pathogenic enteric organisms is their transport and survival in soil after sewage sludge application.

The amount and rates of sewage sludge land-application are currently controlled via guidelines and regulations that set criteria for levels of pathogens, which are protective of the environment and human health (e.g. UK DoE 1989; Wolstenholme et al. 1992; US EPA 1993; NSW EPA 1998; NZWWA 2003). The guidelines require the sewage sludge be treated to such a level that pathogens 
are reduced to below detection limits before land application (Class or Grade A). Alternatively, the sewage sludge can be treated to a lesser degree (Class or Grade B), but adequate time must be allowed for the sewage sludge to remain in or on the land for natural attenuation to further reduce the pathogen numbers before use of the land for cropping or public access. Class or Grade A and B indicator organisms and/or pathogen limit concentrations are shown in Table 1. Faecal coliform counts in Grade or Class B sludges can be high, up to $10^{5} \mathrm{~g}^{-1}$ dry sewage sludge (Vasseur et al. 1996; Davies et al. 1999; LeClerc et al. 2001; Zaleski et al. 2005). In addition to run-off, bypass flow through soils has potential to contaminate surface and groundwater and is a potential public health risk.

Contamination of food and water by micro-organisms from animal manures has become a topic of concern after recent food-poisoning outbreaks (Islam et al. 2005; Johannessen et al. 2005; Cooley et al. 2007). Point sources of animal manure contamination can include animal feedlots, animal housing facilities, manure storage areas and fields where effluent or manures are spread. Rainfall may result in nonpoint-source pathogen contamination by carrying pathogens into nearby fields or surface waters by runoff or by leaching them through the soil into groundwater (Gagliardi and Karns 2000). Factors controlling survival, transport and regrowth include soil type (Mubiru et al. 2000; Aislabie et al. 2001; Cools et al. 2001; Trevisan et al. 2002), agricultural practice (Hutchinson et al. 2004), method of pathogen delivery (i.e. type of waste) (Avery et al. 2004, 2005; Sun et al. 2006) and environmental factors such as rainfall, temperature and humidity (Yeager and Ward 1981; Palacios et al. 2001; Hepburn et al. 2002; Jenkins et al. 2002; Zaleski et al. 2005). It has been shown that if transported below the top layers of the soil, pathogens can survive for extended periods of time after the initial application (Gagliardi and Karns 2000). Some studies with animal waste have shown that the presence of manure can enhance survival of pathogens such as Escherichia coli O157:H7, possibly because of enhanced microsite habitat and the addition of nitrogen (Gagliardi and Karns 2000; Oliver et al. 2006). Sewage sludge storage and application areas could constitute a point source of pathogen contamination, especially where lower grades of sewage sludge are concerned (e.g. Class or Grade B) and where pathogens could still be present.

It is not practicable to monitor sewage sludge for the presence of the wide variety of pathogenic and potentially pathogenic organisms that could be found. A more reasonable approach is to search for indicator organisms and representatives of known pathogenic species to represent the larger set of pathogenic organisms (e.g. Salmonella ssp.; enteric viruses and helminth ova.). Two important human pathogens are Salmonella enterica ssp. enterica serovar Typhimurium-lux (STM-lux) and human adenovirus (HAdV). Salmonella Typhimurium is one of the most common enteric infections in New Zealand [reported incidence rates are $32 \cdot 2$ cases per 100000 persons (New Zealand Public Health Surveillance Report 2008)] and is also able to grow in the environment (Zaleski et al. 2005; Sinton et al. 2007). HAdVs are DNA viruses that cause a wide range of symptoms, are shed in large numbers in faeces and are frequently present at high levels in sewage (Irving and Smith 1981). HAdV may be useful as enteric virus indicators because of their prevalence and apparent environmental stability in environmental samples including wastewaters, sewage sludge and surface waters (Irving and Smith 1981; Enriquez et al. 1995; Pina et al. 1998). In addition, compared to other enteric viruses, HAdVs are reported to be UV light and heat resistant (Meng and Gerba 1996; Gerba et al. 2002). HAdV types 40 and 41 (that cause gastroenteritis) have shown to be more stable in the environment than other enteric viruses (Enriquez et al. 1995).

Detection and quantification of microbes in sewage sludge have inherent difficulties including the following: (i) many tests were developed for clinical material where the pathogen is likely to be present in large numbers relative to other organisms; (ii) techniques can have low

Table 1 Pathogen density limits adapted from United States Environmental Protection Agency (US EPA 1993); New South Wales Environmental Protection Agency (NSW EPA 1998) and New Zealand Waste Water Association (NZWWA 2003)

\begin{tabular}{|c|c|c|c|c|}
\hline \multirow[b]{2}{*}{ Micro-organisms } & \multicolumn{2}{|l|}{ USA } & \multirow{2}{*}{$\frac{\text { New Zealand* }}{\text { Grade A }}$} & \multirow{2}{*}{$\frac{\text { New South Wales* }}{\text { Class A }}$} \\
\hline & Class A & Class B & & \\
\hline Escherichia coli & NA & NA & $<100$ MPN per gram & NA \\
\hline Faecal coliforms & $<1000$ MPN per gram & $<2000000$ MPN per gram & NA & $<1000$ MPN per gram \\
\hline Salmonellae & $<3$ MPN per $4 \mathrm{~g}$ & & $<1$ per $25 \mathrm{~g}$ & Not detected $/ 50 \mathrm{~g}$ \\
\hline Enteric viruses & $<1 \mathrm{PFU}$ per $4 \mathrm{~g}$ & & $<1 \mathrm{PFU}$ per $4 \mathrm{~g}$ & $<1$ PFU per $4 \mathrm{~g}$ \\
\hline Helminth ova & $<1$ per $4 \mathrm{~g}$ & & $<1$ per $4 \mathrm{~g}$ & $<1$ per $4 \mathrm{~g}$ \\
\hline
\end{tabular}

NA, no limits; PFU, plaque-forming unit; MPN, most probable number.

*New Zealand and New South Wales Grade/Class B sludges have no limits for micro-organisms. 
recoveries and be inaccurate; (iii) the waste stream is not an 'optimal' environment for many pathogenic organisms which will be damaged and, therefore, will not grow well in laboratory media (Cooper and Riggs 1994; EC 2001). To try to overcome these difficulties, we spiked sewage sludge with a STM-lux, a Salm. Typhimurium strain containing the bioluminescence gene set 'lux' from the marine bacterium Vibrio fisheri (Redshaw et al. 2007). The reporter system is plasmid based and allows for easy identification of the bacterial cells by their bioluminescent or fluorescent phenotypes, without need for further identification. HAdV type 2 was chosen because of its relative ease of culture compared to HAdV type 40 or 41 , which does not readily culture to high titres and develops cytopathic effects (CPE) relatively slowly. In addition, until recently, there were no reports of a reliable quantitative infectivity assay for types 40 and 41 (Cromeans et al. 2008). In addition to a most probable number (MPN) culture method for infectivity, PCR was also used for the detection of HAdV.

To investigate the survival and transport of sewage sludge-borne pathogenic organisms, sewage sludges were spiked with STM-lux and HAdV type 2 and were applied to the surface of undisturbed soil columns at agronomic rates. The soil columns were irrigated and the leachates collected; the soils were then monitored over a 2-month period for the two pathogens.

\section{Materials and methods}

\section{Preparation of bacterial and virus cultures}

A culture of STM-lux (Redshaw et al. 2007) was grown in $10 \mathrm{ml}$ of Luria-Bertani (LB) broth (10 g tryptone, $5 \mathrm{~g}$ yeast extract, $10 \mathrm{~g} \mathrm{NaCl}, 11$ distilled water) supplemented with $50 \mu \mathrm{g} \mathrm{ml}^{-1}$ of kanamycin (PS; Gibco, Invitrogen Corp.) and $12.5 \mu \mathrm{g} \mathrm{ml}^{-1}$ of tetracyclin (PS; Gibco, Invitrogen Corp.) in a $20-\mathrm{ml}$ thin-walled universal bottle shaken at $180 \mathrm{rev} \mathrm{min}^{-1}$ at $25^{\circ} \mathrm{C}$ until a cell concentration of $10^{8}$ colony-forming units (CFU) $\mathrm{ml}^{-1}$ was obtained (OD of $0 \cdot 8,550 \mathrm{~nm}$ ). The cultures were then centrifuged at $7550 \mathrm{~g}$ for $1 \mathrm{~min}$, washed twice in $1 / 4-$ strength Ringer's solutions (Oxoid Ltd, Basingstoke Hampshire, UK) and concentrated threefold by re-suspension in $3 \mathrm{ml}$ Ringer's. The STM-lux was quantified (CFU) on LB agar supplemented with $50 \mu \mathrm{g} \mathrm{ml}^{-1}$ kanamycin and $12.5 \mu \mathrm{g} \mathrm{ml}^{-1}$ tetracyclin. The bacterial cultures were then stored at $5^{\circ} \mathrm{C}$ until use.

HAdV type 2 [American Type Tissue Culture Collection (ATCC) VR-846] and A549 (human epithelial lung carcinoma cells, ATCC CCL-185) cells were obtained from ATTC (Virginia, USA). The A549 cells (passage $85-95)$ were propagated in $8 \%(\mathrm{v} / \mathrm{v})$ foetal calf serum
(FCS) in medium 199 (Gibco, Invitrogen Corp.), supplemented with 100 units of penicillin $G$ sulfate and $100 \mu \mathrm{g} \mathrm{ml}^{-1}$ of streptomycin sulfate (PS; Gibco, Invitrogen Corp.). HAdV was prepared from infected A549 monolayers by freeze-thaw lysis followed by sonication for $3 \mathrm{~min}$ in an ultrasonic cleaner (Model FX10; Unisonics Pty, Ltd., Sydney, Australia). Lysates were extracted by the addition of an equal volume of chloroform, clarified by low-speed centrifugation $(400 \mathrm{~g}$, $5 \mathrm{~min}$ ) and then filtered through a $0 \cdot 2-\mu \mathrm{m}$ membrane filter (pretreated with FCS) to remove viral aggregates. The preparation was aliquoted and stored at $-70^{\circ} \mathrm{C}$. The infectivity titres of the HAdV stock preparation were determined using serial tenfold dilutions in triplicate 96-well microtitre tissue culture plates. The A549 cells were plated at a concentration of $10^{4}$ cells per well in $2 \%(\mathrm{v} / \mathrm{v})$ FCS in medium 199, followed immediately by the addition of serial dilutions of virus diluted in 2\% (v/v) FCS in medium 199 per well. Plates were incubated at $37^{\circ} \mathrm{C}$ in a humidified $5 \% \mathrm{CO}_{2}$ atmosphere and examined regularly for CPE characteristic of HAdV. Results were expressed as the MPN ml${ }^{-1}$.

\section{Preparation of soils and sewage sludge}

\section{Soil cores}

Twenty-seven undisturbed soil cores were obtained by driving plastic pipes into the soil. The soil selected for the study was a silty clay topsoil overlying clay subsoil under Monterey pines, Pinus radiata, at Tahekeroa Forest, c. $10 \mathrm{~km}$ northwest of Silverdale, North Island, New Zealand (NZMS 260, Q10 472 163). The lysimeters were $100 \mathrm{~mm}$ diameter $\times 200 \mathrm{~mm}$ tall and had a $10 \mathrm{~mm}$ internal annulus filled with petroleum jelly to prevent water preferentially flowing at the soil-casing interface (Cameron et al. 1992). Lysimeters were irrigated with tap water for 1 day to bring the cores to field capacity with leachate emanating from the bottom and then allowed to drain for 2 days before application of the sewage sludge (McLeod et al. 2001).

\section{Sewage sludge}

Fresh anaerobically mesophillically digested, dewatered sewage sludge (c. 18\% solids) was obtained from North Shore City (Rosedale) Wastewater Treatment Plant (Auckland, New Zealand) (Grade B). HAdV and STM-lux were added to sewage sludge to give final concentrations of $6.5 \times 10^{6} \mathrm{CFU} \mathrm{g}^{-1}$ dry weight STM-lux and $10^{6} \mathrm{MPN} \mathrm{g}^{-1}$ dry weight HAdV. For the control lysimeters that did not receive inoculated sewage sludge, STM-lux and HAdV were added to soil to give final concentrations of $9 \cdot 1 \times 10^{5}$ CFU g ${ }^{-1}$ dry weight and $10^{6} \mathrm{~g}^{-1}$ dry weight STM-lux and HAdV respectively. The inoculated sludge and soil were 
incubated at $16^{\circ} \mathrm{C}$ in the dark for 3 days to allow time for the bacteria and viruses to adsorb to the sludges and soils. An incubation temperature of $16^{\circ} \mathrm{C}$ was chosen to allow optimal survival of virus and minimum growth of bacteria. After incubation, the sewage sludge was applied to the surface of 18 replicate lysimeters at two rates: the New Zealand guideline agronomic rate of $200 \mathrm{~kg} \mathrm{~N} \mathrm{ha}^{-1}$ (New Zealand Waste Water Association (NZWWA) 2003) and $600 \mathrm{~kg} \mathrm{~N} \mathrm{ha}^{-1}[3 \times$ the guideline limit (New Zealand Waste Water Association (NZWWA) 2003)]. This equated to 2.7 and $8.1 \mathrm{~g}$ (dry weight) of inoculated sewage sludge per lysimeter. For the controls, $12 \cdot 1 \mathrm{~g}$ (dry weight) of inoculated soil was placed on the surface of nine replicate lysimeters; this equated to the same volume of wet weight sewage sludge at the $200 \mathrm{~kg} \mathrm{~N} \mathrm{ha}^{-1}$ rate.

\section{Leaching experiments}

An artificial rainfall event was simulated by irrigating the lysimeters continuously with tap water at a rate of $5 \mathrm{~mm} \mathrm{~h}^{-1}$ (for $6 \mathrm{~h}$, c. 11 of water) using a drip-type rainfall simulator with drippers $c .100 \mathrm{~mm}$ above the soil surface, immediately after sewage sludge or soil application. Lysimeters were left to drain overnight and leachate samples collected in sterile 1-1 glass bottles and subsampled for STM-lux and HAdV analyses. Determination of any ponding during irrigation was by visual observation. Recovery percentages of STM-lux and HAdV were calculated in the leachate. Following the artificial rainfall event, the lysimeters were weighed and transferred to a light incubator maintained at $16^{\circ} \mathrm{C}$ and $18 \mathrm{~h}$ photoperiod to emulate climatic conditions in Spring/Summer in New Zealand. The soil moisture was maintained by misting weekly with distilled tap water.

\section{Analysis of leachate}

\section{STM-lux}

The method for enumerating STM-lux in leachate was adapted from Part 9222.B, Standard Methods for the Examination of Water and Wastewater (APHA 2006). Leachate samples $(1 \mathrm{ml})$ were diluted in phosphate buffer $(\mathrm{pH} 7 \cdot 0)$ as required and then filtered through celluloseester membrane filters $(0 \cdot 45-\mu \mathrm{m}$ pore size; Sartorius) according to standard procedures (APHA 2006). The filters were placed in duplicate on plates of LB agar supplemented with $50 \mu \mathrm{g} \mathrm{ml}^{-1}$ kanamycin and $12.5 \mu \mathrm{g} \mathrm{ml}^{-1}$ tetracyclin. After overnight incubation at $32^{\circ} \mathrm{C}$, the plates were examined for growth of luminescent colonies. Total STM-lux in the leachate was determined by multiplying $\mathrm{CFU} \mathrm{ml} l^{-1}$ by leachate volume for each individual lysimeter and was expressed as percentage of total STM-lux added.

\section{HAdV}

Viruses from leachates were concentrated by polyethylene glycol (PEG) 6000 precipitation following elution from solids using beef extract solution (Oxoid). Briefly, $200 \mathrm{ml}$ leachate was centrifuged at $10000 \mathrm{~g}$ for $15 \mathrm{~min}$ and supernatant (SN1) recovered. The pellet was resuspended in $10 \mathrm{ml}$ of $10 \%(\mathrm{w} / \mathrm{v})$ beef extract solution and $\mathrm{pH}$ adjusted to 9. Following mixing for $30 \mathrm{~min}$ at room temperature, the solution was centrifuged at $10000 \mathrm{~g}$ for $10 \mathrm{~min}$ and the supernatant (SN2) added to SN1. The $\mathrm{pH}$ was then adjusted to $7 \cdot 2$, followed by the addition of PEG $6000(10 \% \mathrm{w} / \mathrm{v})$ and $\mathrm{NaCl}(2 \% \mathrm{w} / \mathrm{v})$. The solution was then mixed for a minimum of $2 \mathrm{~h}$ at $4{ }^{\circ} \mathrm{C}$ and centrifuged at $10000 \mathrm{~g}$ for $20 \mathrm{~min}$. The pellet was resuspended in $2 \mathrm{ml}$ phosphate-buffered saline (PBS) ( $\mathrm{pH} 7 \cdot 0$ ) and $0.5 \mathrm{ml}$ chloroform was added, mixed for $5 \mathrm{~min}$ and centrifuged at $10000 \mathrm{~g}$ for $15 \mathrm{~min}$. The supernatant was then collected and stored at $-70^{\circ} \mathrm{C}$ until analysis. Total HAdV in the leachate was determined by multiplying PFU ml $\mathrm{m}^{-1}$ by leachate volume for each individual lysimeter and were expressed as percentage of total HAdV added.

The method for enumerating HAdV by culture in leachates was the same as for the HAdV stock preparations except that up to two dilutions per sample were plated out $(1 \mu \mathrm{l}$ and/or $5 \mu \mathrm{l})$ in A549 cells with the MPN ml ${ }^{-1}$ calculated from 48 wells. In addition to the HAdV culture assays, its presence was also determined by HAdV-specific PCR. Viral DNA was extracted $(200 \mu \mathrm{l}$ sample) using the High Pure Viral Nucleic Acid kit (Roche Molecular Biochemicals, Ltd., Mannheim, Germany) and resuspended in $50 \mu$ l elution buffer as per the manufacturer's instructions. HAdV detection was performed using real-time PCR (Heim et al. 2003) with Platinum Quantitative PCR Supermix-UDG One Step System (Gibco, Invitrogen Corporation, Carlsbad, CA, USA) on a Rotor-Gene 3000 real-time thermocycler (Corbett Research Ltd., Sydney, Australia). PCR primers and probes were as described by Heim et al. (2003). Each $25 \mu \mathrm{l}$ reaction contained $2.5 \mu \mathrm{l}$ of DNA, $12.5 \mu \mathrm{l}$ of Platinum Quantitative PCR Supermix-UDG, 0.25 $\mu \mathrm{mol} \mathrm{l}^{-1}$ probe and $0 \cdot 6 \mu \mathrm{mol}^{-1}$ primers (Heim et al. 2003). Following an initial denaturation step for $3 \mathrm{~min}$ at $95^{\circ} \mathrm{C}$, a three-step cycling procedure of denaturation at $95^{\circ} \mathrm{C}$ for $20 \mathrm{~s}$ with annealing step of $55^{\circ} \mathrm{C}$ for $15 \mathrm{~s}$ and extension step at $62^{\circ} \mathrm{C}$ for $1 \mathrm{~min}$ over 45 cycles was used. Anticontamination procedures were followed for all DNA extraction and PCR procedures. Controls included positive and negative controls, an extraction blank and a HAdV plasmid standard. HAdV quantification by PCR was not determined because quantities detected in the soil samples were often below the limits of quantification. The detection limit for HAdV by PCR was calculated as 1 PCR 
unit $\mathrm{ml}^{-1}$ leachate. Raw data were analysed using RotoRGene software (Corbett Research Ltd.).

\section{Analysis of soil}

Destructive harvests took place at $24 \mathrm{~h}\left(T_{0}\right), 1$ month $\left(T_{1}\right)$ and 2 months $\left(T_{2}\right)$ after the simulated rainfall event. At each harvest, three replicate lysimeters from each treatment were removed and soil sampled from different depths $(0-5 \mathrm{~cm}, 5-10 \mathrm{~cm}$ and $10-20 \mathrm{~cm})$. The samples were homogenized in sterile plastic bags and subsamples taken for determining the moisture content.

\section{Moisture contents}

Moisture contents were determined by drying three $10 \mathrm{~g}$ wet samples at $105^{\circ} \mathrm{C}$ for $24 \mathrm{~h}$. An average value for the three replicates was determined and was used to calculate the moisture contents on a dry-weight basis.

\section{STM-lux}

The method for enumerating STM-lux in soils was a fivetube MPN method adapted from Part 9260D, Standard Methods for the Examination of Water and Wastewater (APHA 2006). At each harvest, $10 \mathrm{~g}$ of soil was vortexed briefly with $900 \mathrm{ml}$ of buffered peptone water (BPW) (Difco Co., NZ) (1 in 100 dilution) and then shaken for $15 \mathrm{~min}$ on a reciprocal shaker at $200 \mathrm{rev} \mathrm{min}^{-1}$. Following shaking, further dilutions were obtained through serial diluting into BPW, to allow 'quantitative MPN'. An initial nonselective pre-enrichment step in BPW $\left[16-20 \mathrm{~h}\right.$ at $35^{\circ} \mathrm{C}$ (Mills and Barea 2003)] was then carried out on the diluted samples to allow the recovery of cells that might have been sublethally damaged by physical changes in the environment. After preincubation, $1 \mathrm{ml}$ aliquots of the BPW diluents was transferred into five tubes of $10 \mathrm{ml}$ Rappaport Vassilidiales medium (Difco Co.) (prewarmed to $42^{\circ} \mathrm{C}$ ) followed by incubation at $42^{\circ} \mathrm{C}$ for $24 \mathrm{~h}$. Following incubation, each enrichment tube was streaked onto plates of LB agar supplemented with $50 \mu \mathrm{g} \mathrm{ml}^{-1}$ kanamycin and $12.5 \mu \mathrm{g} \mathrm{ml}^{-1}$ tetracyclin. After overnight incubation at $32^{\circ} \mathrm{C}$, the plates were examined for the growth of luminescent colonies. Final confirmation of colonies was determined using polyvalent ' $\mathrm{O}$ ' and ' $\mathrm{H}$ ' serological tests (Remel Europe Ltd, Dartford, Kent, UK). The detection limit was 1 MPN STM-lux $10 \mathrm{~g}^{-1}$ (wet weight sewage sludge).

\section{HAdV}

Viruses from soil samples were concentrated by PEG 6000 precipitation following virus elution using beef extract (Oxoid Ltd.). Briefly, $150 \mathrm{ml}$ beef extract $(10 \% \mathrm{w} / \mathrm{v})$ was added to $15 \mathrm{~g}$ soil and the $\mathrm{pH}$ adjusted to 9 . The mixture was vigorously shaken for $30 \mathrm{~min}$ and then centrifuged at $10000 \mathrm{~g}$ for $30 \mathrm{~min}$. The $\mathrm{pH}$ was adjusted to $7 \cdot 2$, followed by the addition of PEG $6000(10 \% \mathrm{w} / \mathrm{v})$. The solution was then mixed for a minimum of $2 \mathrm{~h}$ at $4^{\circ} \mathrm{C}$, centrifuged at $10000 \mathrm{~g}$ for $20 \mathrm{~min}$ and the pellet resuspended in $5 \mathrm{ml}$ PBS. Finally, $2 \mathrm{ml}$ chloroform was added to the concentrate, mixed for $5 \mathrm{~min}$ and centrifuged at $10000 \mathrm{~g}$ for $20 \mathrm{~min}$. The supernatant was stored at $-70^{\circ} \mathrm{C}$ until required. Detection of HAdV in soil was the same as for leachates; however, the detection limit for HAdV by PCR was calculated as 33 PCR units gram ${ }^{-1}$ wet weight soil.

\section{Statistical analysis}

\section{Leachate}

Leachate data were transformed to percentage of total bacteria applied to each lysimeter, and percentages were routinely arcsine (square-root) transformed prior to ANOvA analysis. Mean values are presented as backtransformed means, and $95 \%$ confidence intervals were used as a measure of variability within the data set.

\section{MPN analysis}

The confidence limits for MPN population estimates for STM-lux were established by Cochran (1950) and can be calculated from prepared tables (Alexander 1982; Woomer 1994). A compilation of factors based on the rate of dilution and number of tubes per dilution are used in the calculation of the confidence factor. Two population estimates differ significantly $(P=0.05)$ when the upper limit of the lesser estimate does not overlap with the lower limit of the greater estimate (Woomer 1994).

\section{Pathogen die-off (decimal reduction time)}

Decimal reduction time ( $D$ values), which is the number of days required to cause one $\log _{10}$ or $90 \%$ reduction in the initial population (Hutchinson et al. 2004), was calculated from the MPN STM-lux data collected over the three time periods $\left(T_{0}, T_{1}\right.$ and $\left.T_{2}\right)$ at the three depths. The $D$-values were determined from the exponential decay curves for each depth sampled and were given by the equation: $N=N_{0} \mathrm{e}^{k x}$, where $N$ is the number of bacteria; $N_{0}$, number of bacteria at time zero harvest; $k$, constant from equation and $x$, time in days. $D-$ value $=\ln (0.1) / k$. There were insufficient data points to calculate $D$ values for the HAdV. We compared $D$ values by using two-way analysis of variance (ANOVA) and least significance difference testing.

\section{Results}

\section{Leachate}

Both STM-lux and HAdV were detected in leachates from all the lysimeters. HAdV was detected by both culture 
Table 2 Percentage of total Salmonella enterica ssp. enterica serovar Typhimurium-lux (STM-lux) and human adenovirus (HAdV) (95\% confidence interval) in leachate. Arithmetic means of nine replicates followed by the same letter are not significantly different $(P=0 \cdot 05)$

\begin{tabular}{llcc}
\hline Treatment & & & \\
\hline Organism & Control & Sewage sludge $\left(200 \mathrm{~kg} \mathrm{~N} \mathrm{ha}^{-1}\right)$ & Sewage sludge $\left(600 \mathrm{~kg} \mathrm{~N} \mathrm{ha}^{-1}\right)$ \\
\hline STM-lux & $0.55 \%(0 \cdot 25-0 \cdot 95)^{\mathrm{b}}$ & $30 \cdot 00 \%(13 \cdot 88-52 \cdot 26)^{\mathrm{a}}$ & $27 \cdot 94 \%(9 \cdot 89-55 \cdot 16)^{\mathrm{a}}$ \\
HAdV & $0.0002 \%(0.0002-0.0003)^{\mathrm{e}}$ & $0.0774 \%(0.0432-0 \cdot 1214)^{\mathrm{c}}$ & $0.0454 \%(0 \cdot 0287-0.0659)^{\mathrm{d}}$ \\
\hline
\end{tabular}

and PCR. Significantly more STM-lux and HAdV leached through the soil cores when sewage sludge was present (Table 2). In the control lysimeters, $<1 \%$ of the applied STM-lux leached, compared to over $25 \%$ in the sewage sludge treatments. For STM-lux, the amount of sewage sludge (200 kg N ha ${ }^{-1}$ or $600 \mathrm{~kg} \mathrm{~N} \mathrm{ha}^{-1}$ ) applied did not affect leaching (Table 2). For HAdV, although only a very small amount of viable virus was detected in the leachates, significantly fewer viruses were found in the control lysimeters compared to the sewage sludge lysimeters. Significantly more viruses leached in the $200 \mathrm{~kg} \mathrm{~N} \mathrm{ha}^{-1}$ than in the $600 \mathrm{~kg} \mathrm{~N}^{-1}$ treatment.

\section{Soils}

In general, the soils in the sewage sludge-treated lysimeters had greater moisture contents than the control soils (Fig. 1); this was significant in the top $5 \mathrm{~cm}$ of soil for all the sampling dates except the last sampling in the $600 \mathrm{~kg} \mathrm{~N} \mathrm{ha}^{-1}$ treatment.

Immediately following the simulated rainfall event $\left(T_{0}\right)$, STM-lux could be detected at all soil depths, in all treatments (Fig. 2). Highest numbers of STM-lux were found in the top $0-5 \mathrm{~cm}$ of the soils in both the control and sewage sludge treated lysimeters, and there was a steady

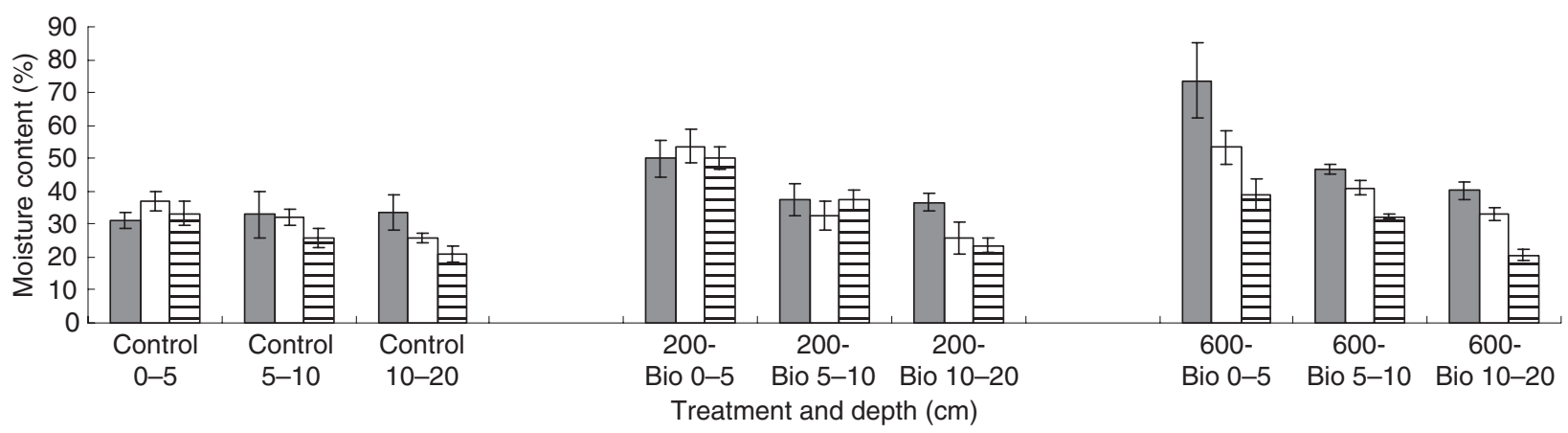

Figure 1 Soil moisture content in cores to which either pathogen contaminated control soil (control); $200 \mathrm{~kg} \mathrm{~N} \mathrm{ha}^{-1}$ or $600 \mathrm{~kg} \mathrm{~N} \mathrm{ha}^{-1}$ sewage sludge (200-Bio; 600-Bio) has been surface applied at different depths $(0-5 \mathrm{~cm}, 5-10 \mathrm{~cm}$ and $10-20 \mathrm{~cm})$. Error bars represent $95 \%$ confidence intervals. ( $\square) T_{0} ;(\square) T_{1}$ and (目) $T_{2}$.

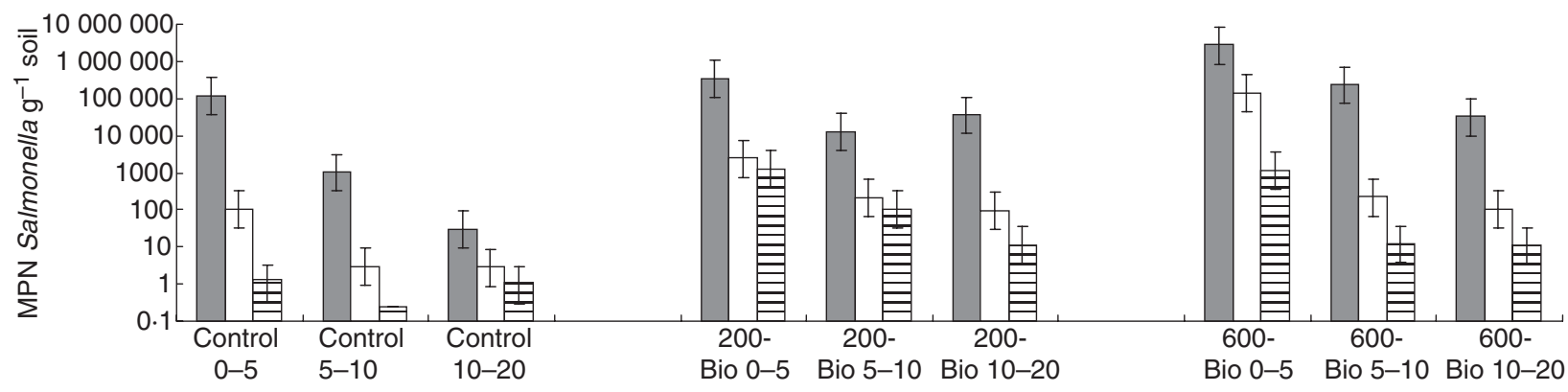

Figure 2 Survival of Salmonella enterica ssp. enterica serovar Typhimurium-lux (STM-lux) in soil cores to which either pathogen contaminated control soil (control); $200 \mathrm{~kg} \mathrm{~N} \mathrm{ha}^{-1}$ or $600 \mathrm{~kg} \mathrm{~N} \mathrm{ha}^{-1}$ sewage sludge (200-Bio; 600-Bio) has been surface applied. Data points represent most probable number estimates of STM-/ux in soil at different depths $(0-5 \mathrm{~cm}, 5-10 \mathrm{~cm}$ and $10-20 \mathrm{~cm})$. Error bars represent $95 \%$ confidence intervals. ( $\square$ ) $T_{0}$; ( $\square$ ) $T_{1}$ and (目) $T_{2}$. 
Table 3 Number of days required for a 1-log decrease in Salmonella enterica ssp. enterica serovar Typhimurium-/ux (STM-/ux) numbers ( $D$ value) in soil cores at different depths $(0-5 \mathrm{~cm}, 5-10 \mathrm{~cm}$ and 10-20 cm). Arithmetic means of nine replicates $( \pm$ SE) followed by the same letter are not significantly different $(P=0.05)$

\begin{tabular}{|c|c|c|c|}
\hline \multicolumn{4}{|c|}{$D$ values (days) for each depth } \\
\hline Treatment & $0-5 \mathrm{~cm}$ & $5-10 \mathrm{~cm}$ & $10-20 \mathrm{~cm}$ \\
\hline Control & $4.1 \pm 0.07^{\text {de }}$ & $4 \cdot 2 \pm 1 \cdot 8^{\mathrm{de}}$ & $3 \cdot 1 \pm 0 \cdot 6^{e}$ \\
\hline $\begin{array}{l}\text { Sewage sludge } \\
\left(200 \mathrm{~kg} \mathrm{~N} \mathrm{ha}^{-1}\right)\end{array}$ & $12 \cdot 7 \pm 2 \cdot 5^{a b c}$ & $10 \cdot 3 \pm 4 \cdot 3^{\mathrm{bcd}}$ & $5 \cdot 4 \pm 3 \cdot 4^{\text {de }}$ \\
\hline $\begin{array}{l}\text { Sewage sludge } \\
\left(600 \mathrm{~kg} \mathrm{~N} \mathrm{ha}^{-1}\right)\end{array}$ & $15 \pm 2 \cdot 7^{\mathrm{ab}}$ & $7 \cdot 8 \pm 0 \cdot 1^{\text {cde }}$ & $19 \cdot 1 \pm 1 \cdot 2^{\mathrm{a}}$ \\
\hline
\end{tabular}

decline in numbers with each subsequent depth. In general, significantly more STM-lux were found at all depths, at all time periods in the sewage sludge treated lysimeters, compared to the controls (Fig. 2). In the control lysimeters, at $T_{2}$, only a small proportion of the original viable cells remained in the cores $(0.01 \%$ in the $0-5 \mathrm{~cm}$ depth) (Fig. 2). High numbers of STM-lux persisted throughout the experiment in the top $0-5 \mathrm{~cm}$ of the soils in the sewage sludge-treated lysimeters, indeed at $T_{2}$, after 2 months, there were still $>10^{3}$ STM-lux present $\left(\mathrm{g}^{-1}\right.$ dry soil) in the top $5 \mathrm{~cm}$ of the soils.

The $D$ values calculated from the decline in STM-lux numbers are shown in Table 3. Significance testing $[P<0.05$ (ANOVA) $]$ revealed that rates of decline for STM-lux in the control lysimeters were more rapid than in the sewage sludge-treated lysimeters. There was no significant difference in STM-lux $D$ values between the $200 \mathrm{~kg} \mathrm{~N} \mathrm{ha}^{-1}$ and $600 \mathrm{~kg} \mathrm{~N} \mathrm{ha}^{-1}$ sewage sludge treatments.

No culturable HAdV was detected in any of the soil depths at any of the sampling periods in the control lysimeter, although HAdV was detected by PCR (two out of three replicates at each soil depth, $0-5 \mathrm{~cm}, 5-10 \mathrm{~cm}$ and $10-20 \mathrm{~cm})$. Viable HAdVs were detected in the
$200 \mathrm{~kg} \mathrm{~N} \mathrm{ha}^{-1}$ and $600 \mathrm{~kg} \mathrm{~N} \mathrm{ha}^{-1}$ sewage sludge treatments immediately following the simulated rainfall $\left(T_{0}\right)$, but only in the $0-5$ and $5-10 \mathrm{~cm}$ soil depths (Table 4 ). Significantly more culturable HAdVs were found in the $600 \mathrm{~kg} \mathrm{~N} \mathrm{ha}^{-1}$ than in the $200 \mathrm{~kg} \mathrm{~N} \mathrm{ha}^{-1}$ biosolid treatment in the $0-5 \mathrm{~cm}$ depth only $\left(T_{0}\right)$. No HAdV was detected at soil depth $10-20 \mathrm{~cm}$ for either sewage sludge treatments.

Although no culturable HAdV was detected at $T_{1}$ or $T_{2}$ in any lysimeter soil, HAdV was detected by PCR only in the $600 \mathrm{~kg} \mathrm{~N} \mathrm{ha}^{-1}$ sewage sludge treatment at $T_{1}$ in soil at $0-5 \mathrm{~cm}$ (three out of three replicate lysimeters) and at $5-10 \mathrm{~cm}$ (one out of three replicate lysimeters) (Table 4). All other samples were negative by PCR at $T_{1}$. Samples taken at $T_{2}$ were not analysed by PCR.

\section{Discussion}

The bioluminescence reporter system used in the STMlux was selected for its utility in visualizing bacteria in biological systems and because cells can be easily identified by their bioluminescent phenotype, without need for further identification. The STM-lux proved very easy to culture and identify with very little background interference. An additional benefit of the lux-based system is the antibiotic-resistance genes carried on the lux plasmid which allows a further selection criterion.

Microbial movement in soils are mainly influenced by soil type and degree of water saturation. Soil type affects adsorption of the microbes to the soil particles (i.e. the degree of filtration potential of the soils); clay and organic matter are the major components affecting adsorption (Sobsey et al. 1980; Aislabie et al. 2001). The presence of macropores and soil structural cracks can increase bypass flow and increase microbial leaching (Gagliardi and Karns 2000; Aislabie et al. 2001). In this study, undisturbed soil columns were used where the natural soil structure remained intact and saturated flow was simulated with a

Table 4 Human adenovirus (HAdV) recovered (MPN $100 \mathrm{~g}^{-1} \pm \mathrm{SE}$ ) in soil cores at different depths $(0-5 \mathrm{~cm}, 5-10 \mathrm{~cm}$ and 10-20 cm). HAdV was added to either soil or sewage sludge, surface applied to the soil and analysed at $T_{0}, T_{1}$ and $T_{2}$ (results not shown for $T_{2}$ ). Numbers of replicate lysimeters $(n=3)$ that were positive by PCR are shown in brackets

\begin{tabular}{|c|c|c|c|c|c|c|}
\hline \multirow{3}{*}{$\frac{\text { Time }}{\text { Treatment }}$} & \multicolumn{6}{|c|}{ HAdV detected (number of lysimeter replicates PCR positive $n=3$ ) } \\
\hline & \multicolumn{3}{|l|}{$T_{0}$} & \multicolumn{3}{|l|}{$T_{1}$} \\
\hline & $0-5 \mathrm{~cm}$ & $5-10 \mathrm{~cm}$ & $10-20 \mathrm{~cm}$ & $0-5 \mathrm{~cm}$ & $5-10 \mathrm{~cm}$ & $10-20 \mathrm{~cm}$ \\
\hline Control & $\begin{array}{l}N D^{*} \\
(2 / 3)\end{array}$ & $\begin{array}{l}N D^{*} \\
(2 / 3)\end{array}$ & $\begin{array}{l}\mathrm{ND}^{*} \\
(2 / 3)\end{array}$ & $\begin{array}{l}N D^{*} \\
(0 / 3)\end{array}$ & $\begin{array}{l}N D^{*} \\
(0 / 3)\end{array}$ & $\begin{array}{l}N D^{*} \\
(0 / 3)\end{array}$ \\
\hline Sewage sludge (200 kg N ha-1) & $\begin{array}{l}36 \pm 11 \cdot 2^{a} \\
(3 / 3)\end{array}$ & $\begin{array}{l}N D^{*} \\
(2 / 3)\end{array}$ & $\begin{array}{l}N D^{*} \\
(1 / 3)\end{array}$ & $\begin{array}{l}2 \pm 1 \cdot 1^{a} \\
(0 / 3)\end{array}$ & $\begin{array}{l}N D^{*} \\
(0 / 3)\end{array}$ & $\begin{array}{l}N D^{*} \\
(0 / 3)\end{array}$ \\
\hline Sewage sludge $\left(600 \mathrm{~kg} \mathrm{~N} \mathrm{ha}^{-1}\right)$ & $\begin{array}{l}115 \pm 49 \cdot 8^{b} \\
(3 / 3)\end{array}$ & $\begin{array}{l}N D^{*} \\
(2 / 3)\end{array}$ & $\begin{array}{l}N D^{*} \\
(1 / 3)\end{array}$ & $\begin{array}{l}2 \pm 1 \cdot 1^{a} \\
(3 / 3)\end{array}$ & $\begin{array}{l}N D^{*} \\
(2 / 3)\end{array}$ & $\begin{array}{l}N D^{*} \\
(1 / 3)\end{array}$ \\
\hline
\end{tabular}

*ND, not detected: below the detection limit of <140 MPN per $100 \mathrm{~g}$ (wet weight). 
heavy rainfall event. Under these conditions, it would be expected that bacteria and viruses should move rapidly through the soils, but in the control lysimeters, $<1 \%$ of the applied bacteria and viruses were recovered in the leachate. For these soils, it is likely that adsorption processes limited microbial leaching, and that the microbes were effectively filtered by the soils. For the sewage-sludge treated soils, the results in this study clearly indicate that the presence of sewage sludge can significantly influence the transport of bacteria and viruses in waste-amended soils. Previous studies have shown that animal manures increased total numbers of E. coli O157:H7 in leachate from intact cores (Gagliardi and Karns 2000); however, it is unclear how the presence of manure aids movement of the microbes. Gagliardi and Karns (2000) determined that E. coli O157:H7 was not attached to leaching particles, although Shelton et al. (2003) did determine a relationship between faecal coliform release and turbidity in studies with dairy manure. Bardford et al. (2006) looked at the transport of Giardia and manure suspensions in a saturated porous media and found that small pores in the soils became filled with manure particles confining both manure particles and Giardia transport to the more larger conductive pore; thus Giardia transport was increased in the presence of manure. Organic matter complicates viral adsorption by adding binding sites to soil (Bixby and O'Brian 1979; Powelson et al. 1991). In this soil type, it is unclear which is the dominant mechanism of increased microbial transport; however, pooling of water was visible on the surface of the sludge-treated lysimeters during the simulated rainfall event suggesting that some pore blockage was occurring. It is thus probable that the filtering of microbes by the soil is inhibited by the presence of sewage sludge which blocks the smaller pores and promotes bypass flow and increased leaching of microbes. It is clear from the results shown in Fig. 2 that bacteria applied to the surface were mainly harboured within the top layer of the soil in both the control and sewage sludge-treated lysimeters; thus, it is probable that straining or sieving at the soil surface, along with adsorption, concentrated bacteria in the top $5 \mathrm{~cm}$ of the soils (Sorber and Moore 1987). In a study investigating the survival of E. coli O157:H7 following the surface and subsurface application of contaminated organic waste, Avery et al. (2004) found that bacteria were also concentrated in the top layer of soils.

When sewage sludge was present, the recovery of STMlux was much greater at all soil depths and all time periods than in control lysimeters with no sewage sludge (Fig. 2). It is possible that the sewage sludge particles provided the bacteria with additional nutrients, and/or that the presence of additional organic matter provided the bacteria with microsites to avoid predation by predators.
In a comparative study, of the decline of E. coli in water, cattle manure and soil incorporated cattle manure, Oliver et al. (2006) found that the most rapid die-off was observed for those cells introduced via sterile water; this may be because the cells had no faecal substrate from which to obtain nutrients nor colloids with which to associate for protection from predators. In control lysimeters, the die-off ( $D$ value, Table 3 ) was increased as compared to the sewage-sludge amended lysimeters; this may have been because STM-lux had to compete more with the soil microflora for available nutrients that were in short supply (Gagliardi and Karns 2000). Although attempts were made to maintain a constant soil moisture in the lysimeters, soils from the control lysimeters were less moist than the sewage sludge-treated soils (Fig. 1). Numerous studies have demonstrated that increased soil moisture increases survival rates of pathogens in soil (Yeager and Ward 1981; Vasseur et al. 1996; Zaleski et al. 2005). It has also been shown that certain conditions, such as increased moisture and carbon availability, can cause re-growth of Salmonella ssp. in biosolids (Soares et al. 1995; Eamens et al. 2006). Therefore, it is possible that a variety of factors including increased moisture, additional nutrients and protection from predation and competition may have increased $D$ values of STM-lux in the sewage sludge-treated lysimeters. Heavy application rates of wastes to soil have been shown to increase soil saturation, which can also increase pathogen mobility and decrease moisture loss, and these can increase survival times (Carrington 2001). In this study, for STM-lux, application rate did not affect numbers in leachate or $D$ values.

The amount of virus recovered in the leachates (control and sludge amended) was extremely low compared to the levels of bacteria observed. Previous studies have demonstrated that viruses may adsorb readily to soils, particularly clay soils and sewage sludge, resulting in a large reduction in virus in the leachate (Bitton et al. 1984; Chetochine et al. 2006). It is probable that the vast majority of viruses added to the sludge became effectively irreversibly bound within sludge particles and/or soil and those that leached from the lysimeter were 'free' virus particles in the aqueous phase. In addition, because of the methods used to extract viruses from soil, it is also possible that the strong adsorption of virus particles to soil particles would result in low recovery during the extraction procedures which would affect the detection sensitivity. If adsorption is the dominant mechanism controlling transport of virus in the environment, then this may explain why significantly more virus leached in the $200 \mathrm{~kg} \mathrm{~N} \mathrm{ha}^{-1}$ than in the $600 \mathrm{~kg} \mathrm{~N} \mathrm{ha}^{-1}$ treatment as increased organic matter may interfere with virus adsorption (Bixby and O’Brian 1979). 
It was interesting to note that viruses were detected by PCR in several cases in soil where no culturable viruses were detected. For example, HAdV DNA was detected in two out of three replicates at $T_{0}$ control lysimeters showing their presence (albeit low levels) at all soil depths despite the failure to grow. One reason may be that PCR will detect viable and nonviable viruses resulting in greater sensitivity. The PCR detected viral DNA at $T_{1}$ at the higher sludge rate $\left(600 \mathrm{~kg} \mathrm{~N} \mathrm{ha}^{-1}\right)$ despite failing to detect any viruses by culture. This may be explained that over time, factors such as microflora presence and temperature can have an effect on virus viability.

It is difficult to assess the survival of HAdV in the lysimeters because of limitations of the methodology; however, the results do suggest that the soil in this experiment is an effective filter for virus particles and that sewage sludge is an unlikely nonpoint source of environmental virus contamination.

The survival, fate and transport of microbial contaminants in sewage sludge applied to land is an important issue with regard to the risk of contamination of the surrounding land and water. The application rate and duration of the rainfall event used in this study is not unusual for a New Zealand winter [New Zealand National Climate Survey, (NIWA 2006)] and would likely cause surface flooding and overtopping of small streams. Although this study indicates a potential risk of environmental contamination from horizontal and vertical movements of sewage sludge-borne bacteria, the limitations must be recognized. Because sewage sludge that is land applied must be treated to provide a significant reduction in pathogens; results from this study may overstate any potential risks as levels of STM-lux and HAdV in spiked samples were significantly greater than what may be expected in treated sewage sludge [e.g. $10^{0}-10^{3} \mathrm{MPN} \mathrm{g}^{-1}$ (Hon 2003; Horswell et al. 2007) and $10^{2}-10^{4} \mathrm{MPN} \mathrm{g}^{-1}$ (Ward et al. 1984) for Salmonella ssp. and HAdV respectively]. However, this study highlights the importance of the pathogen treatment requirements for land-applied sewage sludge as well as the importance of selecting sites with adequate buffers to the receiving environment (e.g. surface water and groundwater).

Once applied to land, natural attenuation can reduce pathogens in the land-applied wastes. However, natural attenuation relies on environmental factors such as temperature, UV exposure and indigenous microbial competition; these will vary from site-to-site and cannot be controlled or predicted. Land management options to avoid scenarios likely to enhance transport and prolong survival (e.g. incorporation of sewage sludge with soil and not applying large inputs of waste) could be a viable approach to minimize nonpoint-source contamination and ensure the least public health risk.

\section{Acknowledgements}

This work was supported by the New Zealand Public Good Science Fund (PGSF). The authors would like to thank Drs Jackie Aislabie and Malcolm McLeod (Landcare Research, NZ) for their assistance with experimental design and Justine Couper for her help with sample collection and analysis.

\section{References}

Aislabie, J., Smith, J.J., Fraser, R. and McLeod, M. (2001) Leaching of bacterial indicators of faecal contamination through four New Zealand soils. Aust J Soil Res 39, 1397-1406.

Alexander, M. (1982) Most probable number method for microbial populations. In Methods of Soil Analysis, Part 2. Chemical and Microbiological Properties - Agronomy Monograph no. 9, 2nd edn. ed. Page, A.L., Miller, R.H. and Keeney, D.R. pp. 815-820. Madison, USA: ASA-SSSA.

American Public Health Association (APHA) (2006) Standard Methods for the Examination of Water and Wastewater (online) ed. Clesceri, L.S., Greenberg, A.E. and Eaton, A.D. Washington, USA: American Public Health Association, the American Water Works Association and the Water Environment Federation.

Avery, L.M., Hill, P., Killham, K. and Jones, D.L. (2004) Escherichia coli $\mathrm{O} 157$ survival following the surface and sub-surface application of human pathogen contaminated organic waste to soil. Soil Biol Biochem 36, 2101-2103.

Avery, L.M., Hill, P., Killham, K. and Jones, D.L. (2005) Survival of Escherichia coli O157 in organic wastes destined for land application. J Appl Microbiol 98, 814-822.

Bardford, S.A., Tadassa, Y.F. and Pachepsky, Y. (2006) Transport of Giardia and manure suspensions in saturated porous media. J Environ Qual 35, 749-757.

Bitton, G., Pancorbo, O.C. and Farrah, S.R. (1984) Virus transport and survival after land application of sewage sludge. Appl Environ Microbiol 47, 905.

Bixby, R.L. and O’Brian, D.J. (1979) Influence of fulvic acid on bacteriophage adsorption and complexation in soil. Appl Environ Microbiol 38, 840-845.

Cameron, K.C., Smith, N.P., McLay, C.D.A., Fraser, P.M., McPherson, R.J. and Harrison, D.F. (1992) Lysimeter without edge flow: an improved design and sampling procedure. Soil Sci Soc Am J 56, 1625-1628.

Carrington, E.G. (2001) Evaluation of Sludge Treatments for Pathogen Reduction - Final Report. Study Contract No B4-3040/2001/322179/MAR/A2 for the European Commission Directorate-General Environment. Luxembourg: European Commission Directorate-General Environment Report No. CO 5026/1.

Chetochine, A.S., Brusseau, M.L., Gerba, C.P. and Pepper, I.L. (2006) Leaching of phage from Class B biosolids and 
potential transport through soil. Appl Environ Microbiol 72, 665-671.

Cochran, W.G. (1950) Estimation of bacterial densities by means of the "most probable number". Biometrics 6, 105-116.

Cooley, M., Carychao, D., Crawford-Miksza, L., Jay, M.T., Myers, C., Rose, C., Keys, C., Farrar, J. et al. (2007) Incidence and tracking of Escherichia coli O157:H7 in a major produce production region in California. PLOS ONE 2, el159 doi: 10.1371/journal.pone.0001159.

Cools, D., Merckx, R., Vlassak, K. and Verhaegen, J. (2001) Survival of E. coli and Enterococcus spp. derived from pig slurry in soils of different texture. Appl Soil Ecol 17, 53-62.

Cooper, R.C. and Riggs, J.L. (1994) Status of pathogen analytical techniques applicable to sewage sludge. In Management of Water and Wastewater Solids for the 21st Century: A Global Perspective-Proceedings of WEF Speciality Conference, June 1994. pp. 13-20. Alexandria, VA: Water and Environmental Federation.

Cromeans, T.L., Lu, X., Erdman, D.D., Humphrey, C.D. and Hill, V.R. (2008) Development of plaque assays for adenoviruses 40 and 41. J Virol Methods 151, 140-145.

Davies, R.D., Carrington, E.G., Gendebien, A., Aitken, M.N., Fenlon, D. and Svoboda, I. (1999) A Users Guide to Research on Application of Organic Wastes to Land. Medmenham: Report SR 4624/3 WRc.

Eamens, G.J., Waldrona, A.M. and Nicholl, P.J. (2006) Survival of pathogenic and indicator bacteria in biosolids applied to agricultural land. Aust J Soil Res 44, 647-659.

Enriquez, C.E., Hurst, C.J. and Gerba, C.P. (1995) Survival of the enteric adenovirus 40 and adenovirus 41 in tap, sea and waste water. Water Res 29, 2548-2553.

European Commission (EC). (2001) Evaluation of Sludge Treatments for Pathogen Reduction. Luxembourg: European Commission Directorate-General Environment, Study contract No. B4-3040/2001/322179/MAR/A2.

Gagliardi, J.V. and Karns, J.S. (2000) Leaching of Escherichia coli $\mathrm{O} 157: \mathrm{H7}$ in diverse soils under various agricultural management practices. Appl Environ Microbiol 66, 877-883.

Gerba, C.P., Gramos, D.M. and Nwachuku, N. (2002) Comparative inactivation of enteroviruses and adenoviruses 2 by UV light. Appl Environ Microbiolol 68, 5167-5169.

Heim, A., Ebnet, C., Harste, G. and Pring-Akerbolm, P. (2003) Rapid and quantitative detection of human adenovirus DNA by real-time PCR. J Med Virol 70, 228-239.

Hepburn, N.F., MacRae, M. and Ogden, I.D. (2002) Survival of Escherichia coli $\mathrm{O} 157$ in abattoir waste products. Lett Appl Microbiol 35, 233-236.

Hon, A. (2003) National Study of Risk Substances in SewageSludge-Phase 1: Literature Review of Existing Knowledge and Identification of Expected Risk Contaminants. Prepared by $\mathrm{CH} 2 \mathrm{M}$ Beca Ltd for the New Zealand Ministry for the Environment.

Horswell, J., Ambrose, V., Clucas, L., Leckie, A., Clinton, P. and Speir, T.W. (2007) Survival of Escherichia coli and
Salmonella spp. after application of sewage sludge to a Pinus radiata forest. J Appl Microbiol 103, 1321-1331.

Hutchinson, M.L., Walters, L.D., Moore, A., Crookes, K.M. and Avery, S.M. (2004) Effect of length of time before incorporation on survival of pathogenic bacteria present in livestock wastes applied to agricultural soil. Appl Environ Microbiol 70, 5111-5118.

Irving, L.G. and Smith, F.A. (1981) One-year study of enteroviruses, adenoviruses and reoviruses isolated from effluent of an activated sludge purification plant. Appl Environ Microbiolol 41, 51-59.

Islam, M., Doyle, M.P., Phatak, S.C., Millner, P. and Jiang, X. (2005) Survival of Escherichia coli O157:H7 in soil and on carrots and onions grown in fields treated with contaminated manure composts or irrigation water. Food Microbiol 22, 63-70.

Jenkins, M.B., Bowman, D.D., Fogarty, E.A. and Ghiorse, W.C. (2002) Cryptosporidium parvum oocyst inactivation in three soil types at various temperatures and water potentials. Soil Biol Biochem 34, 1101-1109.

Johannessen, G.S., Bengtsson, G.B., Heier, B.T., Bredholt, S., Wasteson, Y. and Rørvik, L.M. (2005) Potential uptake of Escherichia coli O157:H7 from organic manure into crisphead lettuce. Appl Environ Microbiol 71, 2221-2225.

LeClerc, H., Mossel, D.A., Edberg, A.S.C. and Struijk, C.B. (2001) Advances in the bacteriology of the coliform group: their suitability as markers of microbial water safety. Annu Rev Microbiol 55, 201-234.

McLeod, M., Aislabie, J., Smith, J., Fraser, R., Roberts, A. and Taylor, M. (2001) Viral and chemical tracer movement through contrasting soils. J Environ Qual 30, 2134-2140.

Meng, Q.S. and Gerba, C.P. (1996) Comparative inactivation of enteric adenovirus, poliovirus, and coliphages by ultraviolet irradiation. Water Res 30, 2665-2668.

Mills, J. and Barea, H. (2003) Effect of Pre-enrichment Incubation Time on Recovery of Salmonella spp. - A review. AgResearch Client Report CR 907 Hamilton, New Zealand: AgResearch.

Mubiru, D.N., Coyne, M.S. and Grove, J.H. (2000) Mortality of Escherichia coli O157:H7 in two soils with different physical and chemical properties. J Environ Qual 29, 1821-1825.

New South Wales Environmental Protection Agency (NSW EPA) (1998) Environmental Guidelines: Use and Disposal of Biosolid Products. Sydney: NSW EPA.

National Institute of Water and Atmosphere (NIWA) (2006) New Zealand National Climate Study. Available at: http:// www.niwa.cri.nz.

New Zealand Public Health Surveillance Report (2008) Vol. 6, Iss. 3, pp. 1176-2888. Wellington, New Zealand: Institute of Environmental Science and Research (ESR) Ltd.

New Zealand Waste Water Association (NZWWA) (2003) Guidelines for the Safe Application of Sewage sludge to Land in New Zealand. Wellington: NZWWA.

Oliver, D.M., Haygarth, P.M., Clegg, C.D. and Heathwaite, A.L. (2006) Differential E. coli die-off patterns associated 
with agricultural matrices. Environ Sci Technol 40, 5710-5716.

Palacios, M.P., Lupiola, P., Tejedor, M.T., Del-Nero, E., Pardo, A. and Pita, L. (2001) Climatic effects on Salmonella survival in plant and soil irrigated with artificially inoculated wastewater: preliminary results. Water Sci Technol 43, 103-108.

Pina, S., Piug, M., Lucena, F., Jofre, J. and Girones, R. (1998) Viral pollution in the environment and in shellfish: human adenovirus detection by PCR as an index of human viruses. Appl Environ Microbiolol 64, 3376-3382.

Powelson, D.K., Simpson, J.R. and Gerba, C.P. (1991) Effects of organic matter on virus transport in unsaturated flow. Appl Environ Microbiol 57, 2192-2196.

Redshaw, N., Dickson, S.J., Ambrose, V. and Horswell, J. (2007) A preliminary investigation into the use of biosensors to screen stomach contents for selected poisons and drugs. Forensic Sci Int 172, 106-111.

Shelton, D.R., Pachepsky, Y.A., Sadeghi, A.M., Stout, W.L., Karns, J.S. and Gburek, W.J. (2003) Release rates of manure-borne coliform bacteria from data on leaching through stony soil. Vadose Zone J 2, 34-39.

Sinton, L.W., Braithwaite, R.R., Hall, C.H. and Lackenzie, M.L. (2007) Survival of indicator and pathogenic bacteria in bovine feces on pasture. Appl Environ Microbiol 73, 7917-7925.

Soares, H., Cardenas, B., Weir, D. and Switzenbaum, M. (1995) Evaluating pathogen regrowth in biosolids compost. BioCycle 36, 70-76.

Sobsey, M.D., Dean, C.H., Knuckles, M.E. and Wagner, R.A. (1980) Interactions and survival of enteric viruses in soil materials. Appl Environ Microbiol 40, 92-101.

Sorber, C.A. and Moore, B.E. (1987) Survival and Transport of Pathogens in Sludge-Amended Soil - A Critical Literature Review. Austin: Department of Civil Engineering, University of Texas. Prepared for US Environmental Protection Agency. EPA/600/2-97/028.

Sun, Y.H., Luo, Y.M., Wu, L.H., Li, Z.G., Song, J. and Christie, P. (2006) Survival of faecal coliforms and hygiene risks in soils treated with municipal sewage sludges. Environ Geochem Health 28, 97-101.

Trevisan, D., Vansteelant, J.Y. and Dorioz, J.M. (2002) Survival and leaching of fecal bacteria after slurry spreading on mountain hay meadows: consequences for the management of water contamination risk. Water Res 36, 275-283.

United Kingdom Department of the Environment (UK DoE) (1989) (Revised 1996) Code of Practice for Agricultural Use of Sewage Sludge. London: HMSO.

United States Environment Protection Agency (US EPA) (1993) Part 503 - Standards for Use and Disposal of Sewage Sludge. Federal Register 58, pp. 9387-9404. Washington, DC: USEPA.

Vasseur, L., Cloutier, C., Labelle, A., Duff, J.-N., Beaulieu, C. and Ansseau, C. (1996) Responses of indicator bacteria to forest soil amended with municipal sewage sludge from aerated and non-aerated ponds. Environ Pollut 92, 67-72.

Ward, R.L., McFeters, G.A. and Yeager, J.G. (1984) Pathogens in Sludge: Occurrence, Inactivation and Potential for Regrowth. Sandia Rept DAND83-0557, TTC-0428, UC-71, Albuquerque: Sandia Natl Labs.

Wolstenholme, R., Dutch, J., Moffat, A.J., Bayes, C.D. and Taylor, C.M.A. (1992) A Manual of Good Practice for the Use of Sewage Sludge in Forestry. Forestry Commission Bulletin 107. London: HMSO.

Woomer, P.L.(1994) Most probable number counts. In Methods of Soil Analysis, Part 2. Microbiological and Biochemical Properties ed. Weaver, R.W., Angle, S., Bottomly, P., Bezdicek, D., Smith, S., Tabatabai, A. and Wollum, A., vol. 5, pp. 59-79. Madison, USA: ASA-SSSA.

New Zealand Medium Scale Topographic Maps 260 Series (NZMS 260) http://www.linz.govt.nz/topography/ topo-maps/nz-med-scale-maps/index.aspx.

Yeager, J.G. and Ward, R.L. (1981) Effects of moisture contents on long-term survival and regrowth of bacteria in wastewater sludge. Appl Environ Microbiol 41, 1117-1122.

Zaleski, K.J., Josephson, K.L., Gerba, C.P. and Pepper, I.L. (2005) Potential regrowth and recolonization of Salmonellae and indicators in sewage sludge and sewage sludgeamended soil. Appl Environ Microbiol 71, 3701-3708. 